Acest articol se citează:

Vrublevschi, A., (2017/2018). Autopercepții ale inteligenței generale și emoționale și relația cu claritatea de sine. Studia Doctoralia. Psychology and Educational Science, 13-14, 22-44.

\title{
AUTOPERCEPȚII ALE INTELIGENȚEI GENERALE ȘI EMOȚIONALE ȘI RELAȚIA CU CLARITATEA DE SINE
}

\author{
Alexandru Vrublevschi, Universitatea din București, Facultatea de \\ Psihologie și Științele Educației \\ E-mail: vrublevalex@gmail.com
}

\begin{abstract}
This article examines the role of self-concept clarity within the self-assessment of both general intelligence and emotional intelligence and the relation between the results of said tests and the self-concept clarity of participants. The objectives of this study are as follows: (1) the preliminary adaptation of the self-concept clarity scale for use with the Romanian population, (2) the reproduction of previous results concerning the correlations between the self-assessments of participants and the results obtained after psychometric testing on a Romanian sample, (3) research into the existence of a negative correlation between self-concept clarity levels and the errors of participants' self-assessments and (4) the exploration of the relationship between selfconcept clarity and the tests used in this study. The sample used in the study was composed of 157 participants that were assessed online with the self-concept clarity scale, were asked to selfassess their general and emotional intelligence levels and then took the GAMA (general intelligence), MSCEIT and EQ-i (emotional intelligence) tests. The results of the study indicate a significant relation between self-concept clarity and the GAMA, MSCEIT and EQ-i test results and encourage further research into the role of self-concept clarity in the self-assessment process.
\end{abstract}

Keywords: self-concept clarity, self-assessment, general intelligence, emotional intelligence.

\section{Introducere}

Oamenii îşi autoevaluează abilităţile în varii situaţii zi de zi. Deşi nu suntem întotdeauna conştienţi de acest proces, tindem să ne evaluăm frecvent capacităţile şi resursele atunci când avem de-a face cu sarcini şi activități noi şi rutiniere deopotrivă. Aceste evaluări se produc rapid şi 
fără prea mult efort cognitiv, spre exemplu: „Pot să ajung la timp la şcoală?" sau „Pot îndeplini această sarcina în timpul rămas?”. Autoevaluarea are astfel un rol major în viața indivizilor permiţându-le acestora să-şi analizeze capacităţile şi să facă alegerile corespunzătoare posibilităţilor lor. Totuşi este această autoevaluare de încredere? $\mathrm{Ne}$ putem baza pe noi înşine să ne autoevaluăm abilităţile într-un domeniu? Care sunt factorii ce influenţează aceste evaluări şi cât de precise sunt ele? Interesul pentru capacitatea oamenilor de a-şi autoevaluă capacităţile provine din două surse. În primul rând, dorim să explorăm care sunt limitele acestor autoevaluări, cât de eficient şi de obiectiv pot oamenii să îşi aprecieze abilităţile şi să observăm în ce contexte sunt folosite acestea. Astfel, putem afla mai multe despre perceptsia asupra sinelui a persoanei respective, modul de construcție al acestei percepții, şi cât de afectată este de factorii interni şi externi individului. Autoevaluările făcute de indivizi sunt vitale pentru buna desfăşurare a activităţilor deoarece, dacă aceste evaluări nu sunt apropiate realităţii, individul va capăta o imagine deformată a realităţii şi va acționa în consecinţă. Aceste fenomene pot varia de la simpla supraestimare a abilităţilor până la promovarea unei imagini false despre sine, o imagine care până la urmă dezavantajează individul, neprezentându-i adevărata natură. Un exemplu puţin mai larg pentru astfel de distorsiuni ale imaginii poate fi lucrarea impresionantă a lui Daniel David (2015). În monografia sa construită cu mult efort, David relevă faptul că românii au în genere o imagine socială deformată despre ei înşişi, percepându-se şi propagând imaginea unui popor cald şi primitor în timp ce studiile ne prezintă ca un popor mai degrabă rece şi sceptic. În al doilea rând, eficienţa autoevaluărilor este studiată pentru a vedea în ce măsură pot suplini un test obiectiv al abilității respective. Aceste nevoi au apărut cel mai des în mediul educaţional şi organizaţional, unde testele sunt folosite des pentru a ajuta în evaluarea indivizilor. Adesea testele profesionale şi competențe pot deveni costisitoare, mai ales când este vorba de un volum mare de oameni, şi atunci este important să studiem în ce măsură putem folosi informațiile provenite din autoevaluările oamenilor. După studierea literaturii din domeniu am observat faptul că autoevaluările indivizilor tind să nu fie suficient de precise pentru a putea înlocui rezonabil un test obiectiv al abilităților şi că adesea sunt influențate de o 
sumedenie de factori ce țin fie de individ, de perspectiva acestuia asupra sinelui şi asupra sarcinii şi a condiţiilor testării, fie de sarcina respectivă în sine (Mabe \& West, 1982; Sundström, 2005). În ceea ce priveşte factorii ce ţin de individ au fost adesea observate corelaţii între autoevaluări şi stimă de sine, percepţia asupra sinelui şi a eficienţei proprii etc (Ackerman \& Wolman, 2007; Cicei, 2012). Pornind de la aceste elemente am explorat şi alte elemente ce sunt legate de percepția individului asupra propriului sine şi am ajuns la claritatea conceptului de sine. Deşi apărut în literatură de aproximativ 20 de ani (Campbell, Trapnell, Heine, Katz, Lavallee \& Lehman, 1996), conceptul nu a fost foarte utilizat în cadrul studiilor iar cele ce îl au în vedere studiază deobicei relaţia dintre acesta şi alte elemente ce ţin de percepția asupra sinelui, performanţă în anumite domenii sau trăsături de personalitate (Campbell et al., 1996; Nezlek, \& Plesko, 2001; Wu, 2009; Cicei, 2012; Hasson-Ohayon, Mashiach-Eizenberg, Elhasid, Yanos, Lysaker \& Roe, 2014). Având în vedere acestea, am pornit cercetarea de faţă pentru a studia relaţia dintre autoevaluările indivizilor şi claritatea conceptului de sine a acestora. Astfel, vom studia capacitatea participanţilor de a-şi autoevalua inteligența generală şi emoțională comparând autoevaluările iniţiale cu rezultatele obținute la testele folosite în măsurarea acestor concepte. După aceasta vom căuta să vedem dacă claritatea conceptului de sine are vreo influenţă asupra capacităţii participanţilor de a face autoevaluări cât mai apropiate de realitate. În plus, vom studia şi relaţia dintre rezultatele la teste şi claritatea conceptului de sine pentru a vedea dacă conceptul ales are vreun rol în performanța participanţilor la testele utilizate. Pentru acest demers vom face în cadrul cercetării şi o adaptare preliminară a unei scale ce măsoară claritatea conceptului de sine, procesul fiind detaliat în cele ce urmează.

\section{Autoevaluarea}

Autoevaluarea a fost definită de Sedikides \& Strube (1997) ca şi „procesul prin care percepția asupra conceptului de sine este negociată şi modificată social". În termeni mai largi, oamenii încearcă să reducă incertitudinile cu privire la abilităţile lor în anumite situații, deobicei când trebuie să participe la activități sau sarcini ce necesită abilitățile respective. Dar bineînțeles apare problema dacă aceste evaluări sunt 
exacte şi dacă ne putem baza pe ele. Ackerman \& Wolman (2007) alcătuiesc în studiul lor o prezentare a studiilor efectuate în ultimii aproximativ 90 de ani, prezentare din care vom reda câteva studii importante. Primul studiu sistematic în această arie de interes a fost elaborat de Cogan, Conklin, and Hollingworth (1915), studiu în care s-a observat o tendință a participanţilor de a se subevalua când venea vorba de trăsături indezirabile şi de a se supraevalua când venea vorba de trăsături dezirabile. Studiul s-a axat pe corespondenţa dintre autoevaluări şi evaluările celor din jur aşa că nu au fost raportate corelaţii între autoevaluările participanţilor şi rezultatele obţinute la testele obiective ce măsurau acele aspecte. Schutte (1929) a elaborat un studiu în care a comparat autoevaluările inteligenței cu rezultatele la testele obiective de inteligenţă şi a observat că în cadrul eşantionului de 110 femei, 64 s-au supraevaluat, 43 s-au subevaluat şi 4 participante s-au autoevaluat perfect. Corelaţia între autoevaluări şi scorurile obţinute nu a fost raportată în studiul original dar a fost estimată de către Ackerman şi Wolman la .60. Arsenian (1942) a examinat şi el corelaţiile între autoevaluările participanţilor şi rezultatele obţinute la testele obiective, autoevaluările fiind făcute atât înainte cât şi după testarea propriu-zisă. Arsenian a avut două concluzii demne de menţionat: În primul rând faptul că asociaţiile dintre autoevaluări şi rezultatele la teste au crescut după testarea propriu-zisă (totuşi datorită modelului cercetării, participanţi diferiţi se aflau în grupurile respective la momentul celor două măsurători) şi în al doilea rând a observat faptul că autoevaluările au scăzut la momentul posttest față de pretest, indicând astfel o mai bună acordare a autoevaluărilor la măsurile obiective după ce testarea avusese loc. Bailey \& Lazar (1976) au găsit corelaţii ce variau între .35 şi .55 în cazul măsurării abilităţilor generale şi ale abilităţilor verbale. Un an mai târziu, DeNisi \& Shaw (1977) au obţinut corelaţii relativ modeste între autoevaluări şi rezultatele la testele obiective ce variau de la .05 pentru abilităţi vizuale până la .41 pentru abilitățile numerice şi au obţinut o corelație de $.26 \mathrm{cu}$ inteligența generală. Mabe \& West (1982) efectuează o meta-analiză în domeniu, meta-analiză ce conţine şi câteva din cercetările numite mai sus. Concluziile meta-analizei nu sunt foarte încurajatoare, coeficientul de corelaţie obţinut fiind de .29. Totuşi, autorii remarcă faptul că într-o mare parte a studiilor analizate au fost prezente 
condiţii nefavorabile măsurării şi că acest coeficient ar putea fi mărit dacă aceste condiţii ar fi controlate. Condițiile care au avut efectul cel mai mare în cadrul măsurătorilor au fost expectanța participanţilor că autoevaluările lor vor fi comparate cu măsurătorile obiective, autoevaluările care presupuneau comparația $\mathrm{cu}$ alte persoane şi nu $\mathrm{cu}$ estimări absolute, experienţa participanţilor cu completarea testelor respective înainte de momentul autoevaluării şi promisiunea confidenţialității rezultatelor făcută participanţilor. Studii mai recente prezintă corelaţii ce variază între .25 şi .39 (Reilly \& Mulhern, 1995; Paulhus \& Morgan, 1997; Rammstedt \& Rammsayer, 2002;). Ackerman şi Wolman (2007) au încercat în studiul lor să țină cont de condiţiile menţionate de Mabe şi West (1982) pentru a maximiza asociaţiile dintre autoevaluările participanţilor şi rezultatele la testele obiective şi s-au focusat pe trei arii specifice de abilităţi: verbale, matematice şi spaţiale. În studiul lor au rezultat corelaţii de .36 , .50 şi .52 pentru abilităţile verbale, matematice şi respectiv spațiale, mai mari decât cele obţinute în studiul original al lui Mabe şi West. De asemenea, au sesizat fenomenul menţionat de Arsenian (1942), mediile autoevaluărilor scăzând de la pretest la posttest în cazul abilităţilor verbale şi matematice, şi într-o mai mică măsură, şi în cazul estimărilor inteligenței generale. În plus, au menționat faptul că variabilele legate de perspectiva asupra propriei eficiente şi a stimei de sine au fost cel mai puternic corelate cu autoevaluările abilităților, stima de sine prezicând semnificativ diferențele individuale în cadrul autoevaluărilor. Autorii au concluzionat că, deşi autoevaluările nu pot înlocui sub vreo formă testările obiective, atâta timp cât se ține cont de anumite condiții, se pot obține informații relativ utile din autoevaluările persoanelor, îndeosebi când vine vorba de abilităţile matematice şi spaţiale şi mai puțin când vine vorba de cele verbale. Dezvoltând perspectiva asupra factorilor ce afectează autoevaluările persoanelor, Sundström (2005) a realizat o analiză a literaturii din acest domeniu şi a identificat o serie de factori ce afectează autoevaluările. Printre aceşti factori se numără competenţa persoanei care este evaluată, persoanele competente putând face autoevaluări mai precise, specificitatea domeniului măsurat sau dificultatea domeniului măsurat.

Astfel, considerăm că: 
H1. Autoevaluările participanților corelează pozitiv cu scorurile obținute în urma testării psihometrice.

\section{Claritatea conceptului de sine}

Campbell et al. (1996) au abordat pentru prima oară intensiv conceptul de claritate de sine, definindu-l ca măsura în care convingerile despre sine sunt clar definite, consistente şi stabile. În articolul lor inițial, autorii au studiat corelaţiile între claritatea conceptului de sine şi stima de sine, dimensiunile Big Five şi atenţia focusată pe sine. Claritatea scăzută de sine a fost asociată, printre altele, cu nivele înalte de Nevrotism, stimă scăzută de sine, Conştiinciozitate scăzută, Agreabilitate scăzută şi o analiză cronică a sinelui. De asemenea, scala de claritate a sinelui a prezis o varianţă unică în cadrul stabilităţii şi a constanței autodescrierilor. Smith, Wethington \& Zhan (1996) studiază relaţia dintre claritatea conceptului de sine şi preferinţele pentru un anume stil de coping, modul în care participantul face față unui anumit eveniment şi modul în care participantul face faţă unui eveniment specific în desfăşurare. Au observat că acest concept a adus o contribuţie pozitivă slabă în cazul stilurilor active (planificarea şi acţionarea) şi o contribuție negativă puternică în cazul stilurilor pasive (spre exemplu negarea). Contribuţia negativă a putut fi replicată şi în cazul coping-ului cu un anumit eveniment şi cu evenimentul în desfăşurare, în timp ce contribuția pozitivă nu a putut fi replicată în aceste cazuri. Bigler, Neimeyer \& Brown (2001) au abordat în studiul lor abilitatea clarităţii conceptului de sine şi a diferenţierii sinelui de a prezice adaptarea psihologică. Participanții au completat chestionare ce măsurau stima de sine, scopul în viaţă, sentimentul de coerență, gradul general de mulţumire, echilibrul emoţiilor, depresia, anxietatea şi flexibilitatea în a dezvălui aspecte despre sine. Adăugarea clarităţii conceptului de sine la modelul folosit a adus creşteri variind de la 9\% până la 33\% în cantitatea de varianța explicată. Studiul a fost replicat şi pe un eşantion de pacienţi psihiatrici, rezultatele indicând din nou relaționarea puternică dintre adaptarea psihologică şi claritatea conceptului de sine, mai puternică decât relaţia dintre diferenţierea sinelui şi adaptarea psihologică. Pornind de la asumpțiile lui Baumeister, Smart \& Boden (1996), Stucke 
\& Sporer (2002) au întreprins un studiu în care au examinat narcisismul şi claritatea conceptului de sine în rolul de predictori ai furiei, depresiei şi agresivităţii verbale în urmă unei ameninţări asupra ego-ului. Rezultatele obţinute au indicat faptul că narcisismul şi claritatea conceptului de sine sunt predictori ai emoţiilor negative şi a agresivităţii după întâlnirea unui eşec, persoanele cu un grad înalt de narcisism şi cu o claritate scăzută a sinelui reacţionând prin furie şi agresivitate în urma eşecului, în timp ce persoanele cu un narcisism scăzut dar cu o claritate înaltă a conceptului de sine au prezentat sentimente de depresie, fără agresivitate. Rezumând, putem observa cum claritatea conceptului de sine a fost legată de-a lungul timpului de diverse concepte precum stilurile de coping, dimensiunile Big Five, stima de sine, introiectarea idealurilor sociale de greutate şi problemele legate de imaginea corporală, adaptarea la stres, agresivitatea, tendinţele de autosabotare, rolul în procesul iertării şi în tehnica piciorului în prag şi aşa mai departe. Aşa cum am menţionat mai devreme, datorită observării efectului stimei de sine asupra autoevaluărilor şi a corelaţiilor obţinute între stimă de sine şi claritatea conceptului de sine, am emis ipoteza conform căreia claritatea conceptului de sine ar putea avea un efect în cadrul autoevaluărilor. Raţionamentul ar fi acela că o persoană cu convingeri clare, stabile, are posibilitatea de a se autoevalua mai corect decât o persoană fără aceste caracteristici. Procesul autoevaluării este influențat după cum am prezentat anterior de diverse concepte ce țin de sine: stimă de sine, percepția cu privire la propria eficientă, percepția asupra sinelui etc. şi atunci este posibil că şi claritatea pe care o are un individ asupra sinelui să influențeze demersul autoevaluării. Un grad crescut de claritate asupra sinelui poate indica o imagine de sine stabilă, construită în timp prin interacțiunile cu mediul şi cu indivizii din jur şi mai aproape de situația reală. Astfel, presupunem că:

H2. Scorul la scala de claritate a conceptului de sine corelează negativ cu eroarea autoevaluărilor participanților.

\section{Inteligenţa generală şi emoţională}

Pentru a studia modul în care interacţionează claritatea conceptului de sine cu autoevaluările indivizilor am selectat testarea 
inteligenței generale şi emoţionale. Am ales aceste două mari domenii pe de-o parte pentru a studia dacă apar diferențe între cele două tipuri de inteligențe atunci când vine vorba de rolul clarității conceptului de sine şi pe de altă parte pentru a studia dacă apar diferențe la nivelul relaţiei cu claritatea conceptului de sine între cele două abordări ale inteligenței emoţionale selectate în cadrul cercetării.

Inteligenţa generală este definită în articolul lui Gottfredson ca şi "o capacitate mentală generală care, printre altele, include abilitatea de a raționa, de a planifica, de a rezolva probleme, de a gândi abstract, de a înţelege idei complexe, de a învăţa rapid şi de a învăţa din experienţă." (Gottfredson, 1997). Inteligenţa este una din marile arii de studiu în cadrul psihologiei, lucru ce se datorează în parte, dar nu numai, faptului că inteligența este un predictor bun atât pentru performanța şcolară (Neisser, Boodoo, Bouchard, Boykin, Brody, Ceci, Halpern, Loehlin, Perloff, Sternberg \& Urbina, 1996) cât şi pentru performanţa la locul de muncă (Schmidt \& Hunter, 1998). Totuşi, testele psihometrice adecvate folosite pentru testarea IQ-ului sunt costisitoare şi se spera, aşa cum am discutat anterior, ca autoevaluarea să fie suficient de capabilă să estimeze IQ-ul astfel încât să servească drept un înlocuitor parţial. Studiile făcute pe validitatea şi precizia autoevaluării inteligenței au produs rezultate ce nu încurajează această direcție, corelațiile oscilând deobicei în jurul unor valori de $\mathrm{r}=0.30$ (Mabe \& West, 1982; Rammstedt \& Rammsayer, 2002; Chamorro-Premuzic \& Furnham, 2014). S-a observat de asemenea faptul că persoanele de sex masculin tind să aibă autoevaluări mai înalte ale inteligenței generale, matematice şi spaţiale decât cele de sex feminin. (Syzmanowicz \& Furnham, 2011).

Pe de altă parte, inteligența emoțională se referă la procesele cognitive implicate în recunoaşterea, utilizarea, înţelegerea şi gestionarea stărilor emoţionale proprii şi ale altor persoane, fiind o aptitudine generală adaptativă utilizată pentru a rezolva probleme şi a regla comportamentul (Mayer \& Salovey, 1997; Salovey \& Mayer, 1990).

Măsurarea inteligenței emoționale este puțin mai dificilă deoarece de-a lungul timpului au apărut diverse teorii cu privire la cum ar trebui abordat acest domeniu. În cercetarea de faţă au fost alese două dintre cele mai cunoscute abordări, cărora le sunt asociate două dintre cele mai folosite teste în domeniul măsurării inteligenței emoționale. Astfel, au 
fost folosite testele EQ-i (Emotional Quotient Inventory) (Bar-On, 1997) şi MSCEIT (Mayer-Salovey-Caruso Emotional Intelligence Test) (Mayer, Salovey \& Caruso, 2002).

Testul EQ-i este construit după modelul lui Reuven Bar-On (BarOn, 2006). Modelul în cauză asociază inteligența emoţională unor comportamente şi abilități specifice şi o defineşte ca fiind un conglomerat de competenţe emoţionale şi sociale interdependente care determină eficienţa cu care putem percepe şi înţelege propria persoană, capacitatea de a ne exprima şi capacitatea de a-i înţelege pe cei din jurul nostru şi de a interacționa eficient cu ei.

Testul MSCEIT este un test de inteligenţă emoţională construit după modelul celor patru ramuri (Four Branch Model) al lui Peter Salovey şi John Mayer (Mayer \& Salovey, 1997). Acesta este singurul test actual ce măsoară abilitatea unui individ în domeniul inteligenței emoționale, acesta trebuind efectiv să îşi folosească capacităţile pentru a răspunde corect la itemii care îi sunt prezentaţi. Autorii definesc inteligența emoțională ca fiind "abilitatea de a percepe cu acuratețe, de a evalua şi de a exprima emoţiile, abilitatea de a accesa şi/sau de a genera sentimente atunci când ele facilitează procesul gândirii, abilitatea de a cunoaşte şi înţelege emoţiile şi abilitatea de a controla emoţiile pentru a promova dezvoltarea emoţională şi intelectuală."

Rolul conceptului în cadrul autoevaluării şi în relație cu inteligenţa generală şi emoţională nu a fost studiat exhaustiv în literatura de specialitate şi atunci am considerat că rezultatele studiului ar putea fi valoroase, indiferent de concluziile la care se va ajunge.

H3. Scorul la scala de claritate a conceptului de sine prezice semnificativ scorurile obținute la testele GAMA, MSCEIT şi EQ-i.

H4. Există o diferență semnificativă între scorurile obținute la testele GAMA, MSCEIT şi EQ-i în funcție de nivelul de claritate al conceptului de sine al participantului. 


\section{Metodologie}

\section{Participanți și procedură}

Eșantionul studiului a fost format din studenții la Facultatea de Psihologie și Științele Educației din cadrul Universității București dispuși să participe la cercetare și din cunoscuții acestora interesați de participare, eșantionarea fiind astfel una de conveniență și de tip "bulgăre de zăpadă" (snowball sampling). Eșantionul inițial a fost format din 189 participanți din care au fost extrasi 32 de participanți deoarece reprezentau valori extreme, eșantionul final fiind format din 157 de participanți, 48 de gen masculin și 109 de gen feminin, cu vârste cuprinse între 17 și 28 de ani $(M=21.73, S D=0.14)$.

Cercetarea s-a desfăşurat după un model clasic cross-secțional, chestionarele folosite au fost împărţite în mediul online tuturor persoanelor care s-au arătat interesate, oferindu-li-se posibilitatea să informeze şi alte cunoştinţe despre cercetare pentru a uşura procesul de strângere a participanţilor. Pachetul de chestionare trimis a fost format dintr-un chestionar google şi trei chestionare de pe platforma testcentral.ro. Chestionarul Google conținea întrebări referitoare la date demografice (vârstă, sex, nume), scala ce măsoară claritatea sinelui şi doi itemi în care participanţii sunt rugaţi să îşi autoevalueze inteligenţa generală şi cea emoţională. Primul din aceşti itemi conţinea o imagine ce reprezenta curba normală a nivelelor IQ la nivelul populaţiei şi avea instrucțiunea: "Figura de mai jos reprezintă distribuția normală a scorurilor IQ-ului care au o medie de 100. Astfel, dacă aveţi IQ-ul de 100 aveți o inteligenţă medie în timp ce un IQ de 130 semnalează o inteligență superioară, iar un IQ de 70 semnalează aproape o deficiență mentală. Ținând cont de această informație, va rugăm să vă notaţi propriul IQ.". Al doilea item este asemănător, prezentând doar modificările necesare pentru a se referi la inteligență emoțională. Datele strânse au fost stocate şi structurate într-o baza de date Excel şi mai apoi analizate cu ajutorul programului statistic SPSS. 


\section{Instrumente}

\section{Claritatea sinelui}

Claritatea sinelui a fost măsurată cu o adapatare a scalei lui Campbell et al.(1996), scală formată din 12 itemi scorati pe scară Likert de la 1 la 5, unde 1 înseamnă "dezacord puternic" și 5 înseamnă "acord puternic" (10 itemi sunt scorați invers iar 2 sunt scorați normal). Un exemplu de item al acestei scale este "În general, am o imagine foarte clară despre cine și ce sunt.". Coeficienții de fidelitate obținuți în studiul lui Campbell sunt de .79 la o reaplicare după 4 luni și de .70 la o reaplicare după 5 luni iar coeficientul de consistență internă obținut în studiul inițial este de .86 .

\section{Inteligența generală}

Inteligența generală a fost măsurată cu testul GAMA (General Ability Measure for Adults) (Naglieri \& Bardos, 1997) utilizat pe platforma testcentral.ro. GAMA este un test rapid, nonverbal, de măsurare a inteligenței ce folosește imagini abstracte pentru a oferi atât un scor general al IQ-ului cât și scoruri pentru 4 subscale (Identități, Analogii, Succesiuni și Construcții). Participantul are 25 de minute la dispoziție să rezolve cât mai mulţi itemi din cei 66 de itemi într-un mod cât mai corect. Coeficientul de consistență internă al scorului IQ rezultat din testarea GAMA variază intre 0.79 și 0.94 de-a lungul diferitelor grupuri normative, cu o medie de .90 . Fidelitatea IQ-ului GAMA este de .67, testată pe un interval intre 2 și 6 săptămani, pe un eșantion de 86 de persoane (Naglieri \& Bardos, 1997).

\section{Inteligența emoțional $\breve{a}$}

EQ-i. Testul este format din 133 de itemi verbali de tip autoevaluare, asemănători celor prezenți într-un test de personalitate. Itemii sunt scorați pe o scară Likert cu cinci variante. Testul are 17 scale (două scale de validare a testului) grupate în cadrul a cinci scale compozite (corespunzătoare celor 5 meta factori). Testul oferă scoruri pentru fiecare scală separată, scoruri pentru scalele compozite și un coeficient al inteligenței emoționale totale. Un exemplu de item al testului EQ-i este "Sunt în contact cu propriile mele emoții". Consistența 
internă a coeficientului pentru inteligența emoțională totală este de .97 , pentru scalele compozite variază între .88 și .93 iar pentru subscale este de la .77 în sus. Coeficientul de fidelitate al testului este de .93 pentru o perioadă de retestare între 2 și 4 săptămani, și de .81 pentru o perioadă de retestare de 8 săptămani (Bar-On, 1997).

MSCEIT. Testul este format din 141 de itemi ce testează aptitudini propriu-zise legate de inteligența emoțională a individului, răspunsurile fiind structurate asemănător celor dintr-un test de inteligență, cu o singură variantă corectă de raspuns. Testul oferă scoruri pentru fiecare subscală, scoruri compozite pentru cele patru scale principale, un coeficient de inteligență emoțională experiențială, un coeficient de inteligență emoțională strategică și un coeficient de inteligență emoțională total. Spre exemplu, un item al scalei Fețe prezintă imaginea unui individ si trei scale asociate diferitelor emotii pe care le-ar putea exprima imaginea (Furie, Tristețe, Fericire etc.). Participantul trebuie să noteze pe o scala de la 1 la 5 cât de vizibilă i se pare fiecare din emoțiile notate. Coeficientul de fidelitate este r=.93 pentru scorarea generală și $\mathrm{r}=.91$ pentru scorarea facută de experți (Mayer, Salovey \& Caruso, 2002).

\section{Rezultate}

În Tabelul 1 sunt prezentate statisticile descriptive ale variabilelor măsurate. Mai întâi s-a realizat o analiză de consistență internă asupra scalei de claritate a sinelui pentru a evalua cum se comportă scala pe eşantionul românesc şi cât de eficient a fost procesul de traducere. S-au studiat corelaţiile Pearson între scorurile la teste, autoevaluările indivizilor, scorul la scala de claritate a sinelui şi diferenţele între autoevaluările indivizilor şi scorurile obţinute (Tabelul 2). S-a efectuat apoi o analiză de regresie pentru a vedea relaţia dintre predictorul clarităţii sinelui şi testele studiate (Tabelul 3). În cele din urmă s-au efectuat teste $t$ pentru a studia dacă există diferențe semnificative între scorurile obținute la testele folosite de către persoanele $\mathrm{cu}$ o claritate a sinelui peste medie şi cele cu o claritate a sinelui sub medie (Tabelul 4). 
Tabelul 1.

Statistici descriptive pentru variabilele măsurate.

\begin{tabular}{lcc}
\hline & $M$ & $S D$ \\
\cline { 2 - 3 } SGAMA & 104.25 & 10.19 \\
SMSCEIT & 104.42 & 8.56 \\
SEQI & 96.79 & 9.45 \\
SC & 41.64 & 8.85 \\
AIQ & 111.01 & 10.21 \\
AEQ & 107.27 & 10.86 \\
DIFGAMA & 10.70 & 8.34 \\
DIFMSCEIT & 9.83 & 9.92 \\
DIFEQI & 11.90 & 10.71 \\
\hline
\end{tabular}

Notă. $M=$ Media. $S D=$ Abaterea standard. SGAMA, SMSCEIT, SEQI= scorurile totale obținute la scorurile respective. $S C=$ scorul la scala ce măsoara claritatea sinelui. $A I Q, A E Q=$ aprecierile participanților asupra inteligenței lor generale si emoționale. DIFGAMA, DIFMSCEIT, DIFEQI= numărul de puncte ce diferă între aprecierea participanților şi scorul real.

Tabelul 2

Corelațiile între variabilele măsurate.

\begin{tabular}{|c|c|c|c|c|c|c|c|c|c|}
\hline & 1 & 2 & 3 & 4 & 5 & 6 & 7 & 8 & 9 \\
\hline 1. SGAMA & $x$ & & & & & & & & \\
\hline 2. SMSCEIT & .07 & $\mathrm{x}$ & & & & & & & \\
\hline 3. SEQI & $.19^{*}$ & $.21^{* *}$ & $x$ & & & & & & \\
\hline 4. SC & $.26^{* *}$ & $.21^{* *}$ & $.46^{* *}$ & $x$ & & & & & \\
\hline 5. AIQ & $.33^{* *}$ & .12 & $.20^{* *}$ & $.20^{*}$ & $x$ & & & & \\
\hline 6. AEQ & .10 & .02 & $.29^{* *}$ & $.25^{* *}$ & $.51^{* *}$ & $x$ & & & \\
\hline 7. DIFGAMA & $-.42^{* *}$ & $-.22^{* *}$ & -.01 & -.06 & $.38^{* *}$ & $.29^{* *}$ & $x$ & & \\
\hline 8. DIFMSCEIT & .05 & $-.28^{* *}$ & -.12 & $-.18^{*}$ & $.21^{* *}$ & $.36^{* *}$ & $.35^{* *}$ & $X$ & \\
\hline 9. DIFEQI & -.00 & -.14 & $-.34^{* *}$ & -.12 & $.35^{* *}$ & $.64^{* *}$ & $.27^{* *}$ & $.45^{* *}$ & $x$ \\
\hline
\end{tabular}

Notă. Notaţiile variabilelor sunt aceleaşi ca in Tabelul 1.

$* p<0.05 ; * * 0<0.01$ 
Tabelul 3.

Analizele de regresie efectuate pe relația predictorului claritate de sine cu rezultatele la cele trei teste folosite.

\begin{tabular}{lcccccc}
\hline Modelul & $R$ & $R^{2}$ & $\begin{array}{c}R^{2} \\
\text { ajustat }\end{array}$ & $\begin{array}{c}\text { Eroarea std.de } \\
\text { estimare }\end{array}$ & df1;df2 & $F$ \\
\hline SC- & .26 & .07 & .06 & 9.85 & $(1,155)$ & $12.11^{*}$ \\
GAMA & & & & & & \\
SC- & .21 & .04 & .04 & 8.39 & $(1,155)$ & $7.47^{*}$ \\
MSCEIT & & & & & & \\
SC-EQI & .46 & .21 & .21 & 8.40 & $(1,155)$ & $42.36^{*}$ \\
\hline $\begin{array}{l}\text { Notă. SC= claritatea conceptului de sine. GAMA, MSCEIT, EQI= rezultatele la testele } \\
\text { respective. }\end{array}$ \\
${ }^{*} p<0.01$
\end{tabular}

Tabelul 4.

Testele t pentru scorurile testelor între eşantionul participantilor cu scoruri sub medie şi peste medie la scala de claritate de sine.

\begin{tabular}{lccccccccc}
\hline & SC Sub medie & $\begin{array}{c}\text { SC Peste } \\
\text { medie }\end{array}$ & & & & $d f$ & $\begin{array}{c}d-u l \\
\text { Coh } \\
\text { en }\end{array}$ & $\begin{array}{c}\text { Interval de } \\
\text { incredere }\end{array}$ \\
& \multicolumn{1}{c}{ M } & $S D$ & $M$ & $S D$ & & & & Min. & Max. \\
\hline G & 101.89 & 10.83 & 106.21 & 9.25 & $-2.69^{* *}$ & 155 & 0.43 & -7.48 & -1.15 \\
M & 102.94 & 9.46 & 105.64 & 7.61 & $-1.98^{*}$ & 155 & 0.31 & -5.38 & -0.09 \\
E & 92.52 & 9.88 & 100.31 & 7.47 & $-5.47^{* *}$ & 128.17 & 0.88 & -10.60 & -4.97 \\
\hline
\end{tabular}

Notă.. $G=G A M A, M=M S C E I T, E=E Q I$

${ }^{*} p<0.05 ;{ }^{* *} p<0.01$

În urma analizei de consistenţă internă s-a obținut un indice ridicat $(\alpha=.88 ; \quad N=12) \quad$ (Popa, 2008), neapărând îmbunătăţiri majore după eliminarea unor itemi cu corelaţii mai scăzute. 


\section{Discuţii}

Primul din obiectivele studiului de faţă a fost să facă o adaptare preliminară a scalei pentru claritatea conceptului de sine. În urma analizei statistice a fost obținut un coeficient de consistență internă de .88. Comparat cu coeficientul obținut în studiul iniţial al autorului scalei de .86 putem concluziona că adaptarea este utilizabilă pentru acest studiu şi alte studii preliminare dar este recomandată o adaptare desfăşurată conform standardelor pentru ca această scala să fie folosită în studii de o mai mare amploare.

Al doilea obiectiv al studiului a fost să verifice dacă rezultatele obținute în studiile anterioare asupra corelaţiei dintre autoevaluările indivizilor şi scorurile obţinute la teste se susţin şi pe un eşantion românesc. Din analizarea rezultatelor putem observa că puterea corelaţiilor în cazul testelor GAMA şi EQ-i este conform celei obţinute anterior (în jurul valorii de $\mathrm{r}=.30$ ). Totuşi, corelaţia în cazul testului MSCEIT se diferențiază de celelalte, puterea corelaţiei în acest caz fiind aproape de zero. Astfel, rezultatele studiului susțin concluziile studiilor anterioare, coeficienţii obţinuţi pe eşantionul românesc fiind asemănători cu cei obținuți în alte țări. Explicaţia pe care am putea-o oferi pentru lipsa corelaţiei între scorurile MSCEIT şi autoevaluările indivizilor este în primul rând lipsa unei clarități asupra conceptului din perspectiva participanţilor la testare. Deşi termenul de "inteligenţă emoţională" este des folosit în ziua de astăzi, mulţi oameni pot avea doar o idee vagă asupra ceea ce reprezintă de fapt inteligenţa emoţională şi care îi sunt comportamentele asociate. Astfel, putem lansa ipoteza conform căreia participanţii la studiu s-au subapreciat sau supraapreciat din cauza acestei neclarităţi şi fie au estimat scorul aleator, din cauză că aveau doar o înțelegere sumară a conceptului, fie au asociat conceptul doar cu o parte din comportamentele şi abilităţile legate de inteligența emoţională, sau chiar cu complet alte comportamente (dacă un participant asociază inteligența emoţională doar cu reziliența la stres el se va autoevalua greşit deoarece nu va lua în calcul capacitatea sa de a-şi înțelege emoțiile proprii, pe ale celor din jur, de a le gestiona etc.). În plus faţă de acest fapt se adaugă strictețea măsurătorii testului MSCEIT. După cum am menţionat şi în descrierea testelor, în timp ce testul EQ-i are o abordare ce studiază preferințele pentru anumite comportamente, 
abordare ce poate lăsa să treacă nemarcate confuzii ale conceptului ca cele descrise mai sus, testul MSCEIT testează efectiv abilităţile participantului asociate inteligenței emoţionale, moment în care toate dimensiunile definite ale inteligenței emoţionale sunt evaluate. Găsim demn a menţiona totuşi faptul că au reieşit corelaţii negative nu foarte puternice, dar semnificative, între scorurile testelor şi numărul de puncte ce diferă între autoevaluările participanţilor şi scorurile respectivelor teste. Datorită acestui fapt putem emite ipoteza conform căreia odată $\mathrm{cu}$ un nivel mai crescut al inteligenței generale sau emoţionale apare şi posibilitatea individului de a se autoevalua mai eficient.

Al treilea obiectiv al studiului a fost cercetarea unei corelaţii negative între scorul la scala de claritate a sinelui şi eroarea autoestimărilor făcute de participanţi. Pentru aceasta s-a analizat corelaţia între scorul la scala de claritate a sinelui şi numărul de puncte ce diferă între autoestimarea făcută de participant şi scorul real. Deşi negative, toate cele trei corelații corespunzătoare diferențelor au valori foarte mici, doar corelaţia corespunzătoare testului MSCEIT fiind semnificativă statistic. Putem concluziona de aici că variabila clarităţii sinelui nu a prezentat efectul preconizat la începutul studiului, ipoteza emisă nefiind susținută de corelaţiile obţinute. Cel mai probabil aici este vorba de un aspect menţionat şi de Campbell et al. (1996) în studiul lor iniţial, şi anume faptul că, deşi persoanele au o imagine clară şi stabilă asupra propriilor valori, această imagine poate să nu fie în conformitate cu realitatea. Astfel, este plauzibil ca o persoană să aibă o imagine clară despre ea însăşi, imaginea unei persoane cu o inteligenţă emoţională ridicată spre exemplu (cauzele putând fi asemănătoare celor întâlnite la punctul anterior), dar realitatea să reflecte altceva. De asemenea, este posibil ca relația dintre claritatea de sine şi autoevaluările personale să existe dar să nu apară în contextul studierii celor două forme de inteligență. Putem emite ipoteza conform căreia datorită structurii conceptului de inteligenţă şi modului în care acesta este perceput, scala folosită în acest studiu să nu fie adecvată pentru a surprinde aceste interacțiuni. Itemii scalei formulează întrebări despre convingerile şi personalitatea participantului, concepte care e posibil să nu se asocieze $\mathrm{cu}$ nivelul inteligențelor acestuia în acest context (este posibil ca o 
persoană să aibă convingeri clare şi stabile dar să nu ştie foarte bine care sunt nivelele inteligenţelor proprii şi invers.).

Al patrulea obiectiv al studiului a fost de a explora relația dintre variabila clarităţii sinelui şi rezultatele testelor aplicate. Mai întâi s-au studiat corelaţiile obținute între variabilele prezentate. Toate corelaţiile obţinute sunt semnificative, corelaţiile cu scorurile GAMA şi MSCEIT fiind medii, iar corelaţia cu scorul EQ-i fiind medie spre mare (Popa, 2008). Folosind aceste rezultate am efectuat o analiză de regresie asupra relaţiilor studiate. Din nou, variabila clarității de sine a prezis în mod semnificativ scorurile testelor, într-o mică măsură în cazul scorurilor GAMA şi MSCEIT, dar într-o măsură sesizabilă în cazul scorurilor EQ-i, procentul varianței explicate fiind aproximativ $20 \%$. In cele din urmă sau efectuat teste $t$ pentru a studia dacă există diferențe între persoanele cu scoruri peste medie la scala de claritate de sine şi cei cu scoruri sub medie. S-au obținut diferențe semnificative în cazul tuturor testelor studiate, cu mărimi ale efectului medii în cazul scorurilor GAMA şi MSCEIT şi cu o mărime a efectului ridicată în cazul scorurilor EQ-i. Toate aceste rezultate susţin existenţa unor relaţii puternice şi semnificative între variabilele studiate, în special în cazul relaţiei cu testul EQ-i. Faptul că relaţia cu EQ-i apare că fiind cea mai puternică poate fi explicată din nou prin modul în care este construit testul. Modelul lui Bar-On structurează testul EQ-i ca un test de personalitate, itemii apropiindu-se astfel de domeniul sinelui şi al introspecţiei. O persoană care are scoruri înalte la testul EQ-i va avea cel mai probabil tendinţa de a se gândi la imaginea de sine, de a-şi analiza sentimentele, de a fii introspectivă destul de des, aceste comportamente fiind în general asociate cu o claritate de sine crescută. Astfel, este plauzibilă ideea că o persoană cu convingeri şi o personalitate clară va obține scoruri mai mari la testul EQ-i. În fine, elementul capacităţii intrapersonale din modelul lui Bar-On măsoară unele arii care se pot suprapune cu domeniul clarităţii sinelui, precum cel al conştiinţei de sine emoționale. 
Studiul de faţă şi-a propus să cerceteze relaţia dintre autoevaluarea inteligenţei generale şi emoţionale şi claritatea conceptului de sine. Pentru aceasta, au fost studiate corelaţiile dintre autoevaluările participanţilor şi rezultatele obţinute la testele de inteligenţă generală şi emoţională, corelaţiile între gradul de claritate a conceptului de sine al participanţilor şi diferenţele dintre autoevaluări şi rezultatele obţinute la teste şi relaţia dintre rezultatele obţinute la teste şi gradul de claritate a conceptului de sine. Corelaţiile obţinute între autoevaluările participanţilor şi rezultatele obţinute la testele de inteligenţă generală şi emoţională au fost în mare conform celor obținute în studiile anterioare, cu excepția testului MSCEIT unde corelaţia este aproape inexistentă.

Corelațiile dintre claritatea conceptului de sine şi erorile de autoevaluare au fost negative dar nesemnificative statistic. Claritatea conceptului de sine a prezis semnificativ rezultatele la testele de inteligenţă generală şi emoţională, cea mai puternică relație apărând în cazul testului EQ-i. De asemenea, au fost diferențe semnificative în ceea ce priveşte scorurile la testele de inteligenţă generală şi emoţională între persoanele cu o claritate mică a conceptului de sine şi cele cu o claritate mare. Rezultatele obținute conferă importanță scalei de claritate a sinelui. Pe lângă corelațiile obținute în studiul iniţial cu componentele Big Five şi elemente ale sinelui şi analizei acestuia şi multiplele legături evidenţiate în studiile ulterioare, studiul de faţă oferă date ce susţin ideea unor relaţii cu inteligenţă emoţională şi, într-o mai mică măsură, cu inteligență generală. Influența preconizată a clarității de sine în cadrul procesului de autoevaluare nu este susținută de rezultatele studiului dar, date fiind limitările multiple ale studiului, această ipoteză ar trebui studiată în continuare, în circumstanțe mai adecvate.

\section{Limite ale cercetării şi direcţii viitoare}

Aşa cum am mai menţionat de-a lungul lucrării, studiul are multiple limitări care, odată controlate, pot îmbunătăti rezultatele obținute şi susţine mai consistent concluziile extrase. Considerăm ca limite ale cercetării următoarele elemente:

Eşantionul nereprezentativ pentru populaţia studiată este una din limitele studiului. Pe lângă numărul redus de participanţi, compoziţia formată majoritar din participanți în jurul vârstei de 21 de ani, de gen 
feminin a eşantionului selectat prezintă de asemenea un dezavantaj pentru studiul de faţă. De asemenea, o bună parte din participanţi au fost studenți ai facultăţii de psihologie, acest lucru putând influența acuratețea autoevaluărilor acestora deoarece există o probabilitate mai mare ca aceştia să cunoască mai bine conceptele şi testele folosite în acest studiu decât persoane ce nu studiază psihologia. Un eşantion echilibrat, cu o distribuție normală pe genuri şi vârste va produce cu siguranţă rezultate mai robuste, fie că susțin concluziile studiului de faţă sau dimpotrivă.

O altă limita a studiului de faţă constă în faptul că testele şi chestionarele au fost aplicate integral pe internet. În acest fel nu se pot controla în niciun fel condiţiile în care participanţii completează chestionarele, putând fi influenţaţi de o serie de factori ce pot afecta rezultatele. Bineînţeles că o astfel de aplicare conferă mult mai multă flexibilitate în procesul de strângere de date şi numai prin această metodă am putut ajunge la eşantionul de față dar într-un studiu viitor ar fi recomandată controlarea mai strictă a factorilor ce pot influenţa precizia testelor.

Aşa cum am mai menţionat, traducerea scalei este una preliminară şi nu respectă standardele actuale folosite în adaptarea testelor. Deşi rezultatele obţinute în cadrul studiului sunt încurajatoare, o traducere adecvată poate îmbunătăţi considerabil caracteristicile scalei şi îi poate creşte validitatea.

O altă limită întâlnită în cadrul studiului este legată de autoevaluările făcute de participanţi. Multiplii participanţi din studiu care au notat autoevaluări foarte mari au fost întrebați ce i-a făcut să aleagă valoarea respectivă şi au susţinut că mai completaseră teste de inteligenţă generală sau emoţională înainte şi că acestea fuseseră rezultatele obținute. Pentru clarificare, un exemplu ar fi o autoevaluare a inteligenței generale la un scor de 140. Astfel testele învechite sau testele gratuite de pe internet pot influență participanţii şi pot duce la alterarea rezultatelor. Tot legat de procesul de autoevaluare menţionăm şi itemul de autoevaluare în sine, este posibil ca instructajul oferit participanţilor să nu le fi conferit suficient de clar dimensiunile în cauza, termenul de "supradotat" neoferind o imagine precisă asupra proporţililor în care este împărţită populaţia. Recomandăm pe viitor adăugarea la instructaj 
a unor fraze care să conțină procentajul din totalul populaţiei care se află peste pragul de 120 de puncte IQ.

Ca direcții viitoare de studiu, pe lângă simpla îmbunătăţire şi eficientizare a studiului de faţă în funcţie de limitele expuse anterior, putem indica studierea mai amănunţită a autoevaluărilor şi exactitatea acestora pe populaţia românească, explorarea în continuare a relaţiilor clarităţii sinelui cu alte variabile, studierea unor posibile efecte de moderarea a acesteia în cadrul unor corelaţii şi chiar alcătuirea unei baze de date care să indice situaţia privitoare la starea clarităţii sinelui în ţară noastră.

\section{Bibliografie}

Ackerman, P. L., \& Wolman, S. D. (2007). Determinants and validity of self-estimates of abilities and self-concept measures. Journal of Experimental Psychology: Applied, 13(2), 57.

Arsenian, S. (1942). Own estimate and objective measurement. Journal of Educational Psychology, 33, 291-302.

Bailey, K. G., \& Lazar, J. (1976). Accuracy of self-ratings of intelligence as a function of sex and level of ability in college students. Journal of Genetic Psychology, 129, 279-290.

Bar-On, R. (1997). The Emotional Quotient Inventory (EQ-i): A test of emotional intelligence.Toronto: Multi-Health Systems, 28.

Baumeister, R. F., Smart, L., \& Boden, J. M. (1996). Relation of threatened egotism to violence and aggression: the dark side of high selfesteem.Psychological review, 103(1), 5.

Bigler, M., Neimeyer, G. J., \& Brown, E. (2001). The divided self revisited: Effects of self-concept clarity and self-concept differentiation on psychological adjustment. Journal of Social and Clinical Psychology, 20(3), 396-415.

Campbell, J. D., Trapnell, P. D., Heine, S. J., Katz, I. M., Lavallee, L. F., \& Lehman, D. R. (1996). Self-concept clarity: Measurement, personality correlates, and cultural boundaries. Journal of personality and social psychology, 70(1), 141.

Chamorro-Premuzic, T., \& Furnham, A. (2014). Personality and intellectual competence. Psychology Press. 
Cicei, C. C. (2012). Examining the Association Between Self-Concept Clarity and Self-Esteem on a Sample of Romanian Students. Procedia-Social and Behavioral Sciences, 46, 4345-4348.

Cogan, L. C., Conklin, A. M., \& Hollingworth, H. L. (1915). An experimental study of self-analysis, estimates of associates, and the results of tests. School \& Society, 2, 171-179.

David, D. (2015). Psihologia poporului român: profilul psihologic al românilor intr-o monografie cognitiv-experimentală. Polirom.

DeNisi, A. S., \& Shaw, J. B. (1977). Investigation of the uses of abilities. Journal of Applied Psychology, 62, 641-644.

Gottfredson, L. S. (1997). Mainstream science on intelligence: An editorial with 52 signatories, history, and bibliography. Intelligence, 24(1), 13-23.

Hasson-Ohayon, I., Mashiach-Eizenberg, M., Elhasid, N., Yanos, P. T., Lysaker, P. H., \& Roe, D. (2014). Between self-clarity and recovery in schizophrenia: reducing the self-stigma and finding meaning. Comprehensive psychiatry, 55(3), 675-680.

Mabe, P. A., \& West, S. G. (1982). Validity of self-evaluation of ability: A review and meta-analysis. Journal of applied Psychology, 67(3), 280.

Mayer, J.D., \& Salovey, P. (1997). What is emotional intelligence? In P. Salovey \& D. Sluyter (Eds.), Emotional development and emotional intelligence: Educational implications (pp. 3-31). New York: Basic Books.

Mayer, J. D., Salovey, P., \& Caruso, D. R. (2002b). Mayer-Salovey-Caruso Emotional Intelligence Test (MSCEIT) user's manual. Toronto, Ontario, Canada: MHS Publishers.

Naglieri, J. A., \& Bardos, A. N. (1997). General ability measure for adults. Minneapolis, MN: National Computer Systems.

Neisser, U., Boodoo, G., Bouchard Jr, T.J., Boykin, A.W., Brody, N., Ceci, S.J., Halpern, D.F., Loehlin, J.C., Perloff, R., Sternberg, R.J. and Urbina, S. (1996). Intelligence: knowns and unknowns. American psychologist, 51(2), 77.

Nezlek, J. B., \& Plesko, R. M. (2001). Day-to-day relationships among self-concept clarity, self-esteem, daily events, and mood. Personality and Social Psychology Bulletin, 27(2), 201-211. 
Paulhus, D. L., \& Morgan, K. L. (1997). Perceptions of intelligence in leaderless groups: the dynamic effects of shyness and acquaintance. Journal of personality and social psychology, 72(3), 581.

Popa, M. (2008). Statistică pentru psihologie: teorie şi aplicaţii SPSS. Polirom.

Rammstedt, B., \& Rammsayer, T. H. (2002). Self-estimated intelligence: Gender differences, relationship to psychometric intelligence and moderating effects of level of education. European Psychologist, 7(4), 275.

Reilly, J., \& Mulhern, G. (1995). Gender differences in self-estimated IQ: The need for care in interpreting group data. Personality and individual Differences,18(2), 189-192.

Salovey, P., \& Mayer, J. D. (1990). Emotional intelligence. Imagination, cognition and personality, 9(3), 185-211.

Schmidt, F. L., \& Hunter, J. E. (1998). The validity and utility of selection methods in personnel psychology: Practical and theoretical implications of 85 years of research findings. Psychological bulletin, 124(2), 262.

Schutte, T. H. (1929). Students' estimates of their ability and achievement. Journal of Educational Research, 20, 394-396.

Sedikides, C., \& Strube, M. J. (1997). Self-evaluation: To thine own self be good, to thine own self be sure, to thine own self be true, and to thine own self be better. Advances in experimental social psychology, 29, 209-269.

Smith, M., Wethington, E., \& Zhan, G. (1996). Self-concept clarity and preferred coping styles. Journal of Personality, 64(2), 407-434.

Stucke, T. S., \& Sporer, S. L. (2002). When a grandiose self-image is threatened: Narcissism and self-concept clarity as predictors of negative emotions and aggression following ego-threat. Journal of personality, 70(4), 509-532.

Sundström, A. (2005). Self-assessment of knowledge and abilities: A literature study. [Report]. Retrieved from http://www.divaportal.org/smash/record.jsf?pid=diva2\%3A154084\&dswid=_new

Syzmanowicz, A., \& Furnham, A. (2011). Gender differences in selfestimates of general, mathematical, spatial and verbal 
intelligence: Four meta analyses. Learning and Individual Differences, 21(5), 493-504.

$\mathrm{Wu}, \mathrm{C} . \mathrm{H}$. (2009). The relationship between attachment style and selfconcept clarity: The mediation effect of self-esteem. Personality and Individual Differences, 47(1), 42-46.

Acest articol se citează:

Sîrbu, A.-A., (2017/2018). Investigarea relației dintre plictiseală și comportamentele contraproductive la locul de muncă. Rolul stilurilor de umor. Studia Doctoralia. Psychology and Educational Science, 13-14, $45-62$ 